\title{
THE DETERMINATION OF UNEVEN PULMONARY BLOOD FLOW FROM THE ARTERIAL OXYGEN TENSION DURING NITROGEN WASHOUT
}

\author{
By THEODORE N. FINLEY * \\ (From the Cardiovascular Research Institute, University of California Medical School, \\ San Francisco, Calif.)
}

(Submitted for publication January 3, 1961 ; accepted May 29, 1961)

Many tests are available for measuring unevenness of pulmonary ventilation. In recent years tests of unevenness of pulmonary blood flow have been described, which utilize radioactive krypton (1) in patients with emphysema, radioactive oxygen in patients with mitral stenosis (2), and radioactive carbon dioxide in normal subjects (3). These studies provide quantitative data on the degree of unevenness of pulmonary blood flow but require expensive and complicated apparatus and are not easily adapted to clinical pulmonary function testing. Simpler methods of estimating unevenness of blood flow in relation to ventilation have been suggested. These are based on the rate of rise of arterial oxygen saturation (ear oximeter) during the inhalation of oxygen (4-6), analysis of gas samples obtained from various lobes of the lungs (7), continuous analysis of a single expiration (8), and the difference between the nitrogen tension of alveolar gas and urine (9, 10). These simpler methods do not provide quantitative data on the degree of unevenness of pulmonary blood flow.

An ingenious graphical method of determining unevenness of perfusion of the lung in patients with chronic pulmonary emphysema has been worked out by Briscoe and co-workers (11). This method utilizes a nitrogen washout and wash-in technique and the arterial saturation cluring air-breathing. Its disadvantage is that other causes of arterial desaturation-i.e., shunts and diffusion barriers-cause an overestimation of the degree of unevenness of perfusion.

In this laboratory we have devised a test which yields quantitative data for the determination of the fractional alveolar ventilation and pulmonary capillary blood flow that go to the well and poorly ventilated regions of the

* Fellow of the National Tuberculosis Association. Supported in part by USPHS Grant H-4029. lungs. The test requires the use of a nitrogen meter and a flow-through cuvet $\mathrm{O}_{2}$ electrode for measuring arterial $\mathrm{Po}_{2}$ continuously during the inhalation of $\mathrm{O}_{2}$. In practice the test takes approximately 20 minutes and the calculations another 20 minutes. This method is based on the principle that the rate of rise of alveolar $\mathrm{O}_{2}$ tension during oxygen inhalation depends on the distribution of inspired $\mathrm{O}_{2}$ to well and poorly ventilated regions of the lung (in relation to their volume), while the rate of simultaneous rise of arterial $\mathrm{O}_{2}$ tension depends on the distribution of pulmonary blood flow to these regions and the anatomical shunts. The theory, method and results of these studies in normal subjects and in patients with cardiac and pulmonary disease are presented here.

\section{THEORY}

The lungs can be divided into a well ventilated region (which need not be homogeneous) and a poorly ventilated region (subscripts 1 and 2, respectively). Arterial blood is a mixture of blood that has passed through these regions or through venous-to-arterial shunts. Its oxygen content $\left(\mathrm{C}_{\mathrm{a}}\right)$ is related to the blood flows through the capillaries of the various regions $\left(\dot{Q}_{1}, \dot{Q}_{2}\right)$ and through the shunt $\left(\dot{Q}_{8}\right)$, and to their respective oxygen contents $\left(\mathrm{C}_{1}, \mathrm{C}_{2}\right.$ and $\left.\mathrm{C}_{\overline{\mathrm{v}}}\right)$ as follows:

$$
\mathrm{C}_{\mathrm{a}} \cdot \dot{\mathrm{Q}}_{\mathrm{T}}=\mathrm{C}_{1} \cdot \dot{\mathrm{Q}}_{1}+\mathrm{C}_{2} \dot{\mathrm{Q}}_{2}+\mathrm{C}_{\mathrm{v}} \dot{\mathrm{Q}}_{\mathrm{s}}
$$

where $\dot{Q}_{1}+\dot{Q}_{2}+\dot{Q}_{s}=\dot{Q}_{\mathrm{T}}$, the cardiac output. In this and subsequent formulations we omit, from our otherwise conventional (12) symbolization, the subscript c for capillary and the chemical subscript $\mathrm{O}_{2}$.

It follows from Equation 1 that at any time $(t)$ during the $\mathrm{N}_{2}$ washout:

$$
\begin{aligned}
\mathrm{Ca}_{t}=\mathrm{C}_{1 t}\left(\frac{\dot{\mathrm{Q}}_{1}}{\dot{\mathrm{Q}}_{1}+\dot{\mathrm{Q}}_{2}}\right)+ & \mathrm{C}_{2 t}\left(\frac{\dot{\mathrm{Q}}_{2}}{\dot{\mathrm{Q}}_{1}+\dot{\mathrm{Q}}_{2}}\right) \\
& -\left(\mathrm{C}_{\mathrm{s}}-\mathrm{C}_{\mathrm{v}}\right)_{t}\left(\frac{\dot{\mathrm{Q}}_{s}}{\dot{\mathrm{Q}}_{1}+\dot{\mathrm{Q}}_{2}}\right)
\end{aligned}
$$

We assume the following are constant in the later stages of the $\mathrm{N}_{2}$ washout: 1 ) the magnitude of the various blood flows $\left(\dot{Q}_{1}, \dot{Q}_{2}, \dot{Q}_{s}, \dot{Q}_{\mathrm{T}}\right)$ relative to each other; 2$)$ the arteriovenous $\mathrm{O}_{2}$ content difference $\left(\mathrm{C}_{\mathrm{a}}-\mathrm{C}_{\overline{\mathrm{v}}}\right)$. When we then 
consider the difference between the final equilibrium state at time $f$ and the changing state at time $t$, it follows that:

$$
\begin{aligned}
\mathrm{Ca}_{f}-\mathrm{Ca}_{t}=\left(\mathrm{C}_{1 f}-\mathrm{C}_{1 t}\right) & \left(\frac{\dot{\mathrm{Q}}_{1}}{\dot{\mathrm{Q}}_{1}+\dot{\mathrm{Q}}_{2}}\right) \\
& +\left(\mathrm{C}_{2 f}-\mathrm{C}_{2 t}\right)\left(\frac{\dot{\mathrm{Q}}_{2}}{\dot{\mathrm{Q}}_{1}+\dot{\mathrm{Q}}_{2}}\right)
\end{aligned}
$$

Late in the washout when hemoglobin is fully saturated in all parts of the lung, further changes in $\mathrm{O}_{2}$ content are linearly related to changes in $\mathrm{O}_{2}$ tension (13). Equation 3 can then be formulated in terms of differences in $\mathrm{Po}_{2}$ :

$$
\begin{aligned}
\mathrm{Pa}_{f}-\mathrm{Pa}_{t}=\left(\mathrm{P}_{1 f}-\mathrm{P}_{1 t}\right) & \left(\frac{\dot{\mathrm{Q}}_{1}}{\dot{\mathrm{Q}}_{1}+\dot{\mathrm{Q}}_{2}}\right) \\
& +\left(\mathrm{P}_{2 f}-\mathrm{P}_{2 t}\right)\left(\frac{\dot{\mathrm{Q}}_{2}}{\dot{\mathrm{Q}}_{1}+\dot{\mathrm{Q}}_{2}}\right)
\end{aligned}
$$

Any $\mathrm{PO}_{2}$ gradient due to diffusion difficulty becomes infinitesimal at this time when $\mathrm{Po}_{2}$ is high in all alveoli (13-15). Alveolar and end-capillary oxygen tensions are thus identical within a region; i.e., $\mathrm{PA}_{A_{1}}=\mathrm{P}_{1}, \mathrm{P}_{\mathrm{A}_{2}}=\mathrm{P}_{2}$. If $\mathrm{PCO}_{2}$ is constant within each region, then $\mathrm{Po}_{2}$ is related to $\mathrm{PN}_{2}$, provided that the total pressure of all gases is constant, as it is, in each region, and hemoglobin is fully saturated, as it is, at this time. Then:

$$
\begin{aligned}
\mathrm{Pa}_{f}-\mathrm{Pa}_{t}=\Delta \mathrm{P}_{\mathrm{N}_{2}} & \left(\frac{\dot{\mathrm{Q}}_{1}}{\dot{\mathrm{Q}}_{1}+\dot{\mathrm{Q}}_{2}}\right) \\
& +\Delta \mathrm{P}_{2_{2}}\left(\frac{\dot{\mathrm{Q}}_{2}}{\dot{\mathrm{Q}}_{1}+\dot{\mathrm{Q}}_{2}}\right)=\Delta \mathrm{P}_{\mathrm{C}_{2}}
\end{aligned}
$$

where the various values of $\Delta \mathrm{PN}_{2}$ are the excess at time $t$ over the final ${ }^{1}$ value at time $f . \Delta \mathrm{P}_{\mathrm{N}_{2}}$ is the mean value of this excess in mixed end-capillary blood. This relation holds, regardless of the number of regions.

Late in the washout the concentration of nitrogen has become negligible in all but the worst ventilated region. The contributions of $\mathrm{N}_{2}$ from the inspired $\mathrm{O}_{2}$ tank and from the tissues are virtually constant; while they affect the final value they are of no significance in these considerations of the changes in $\mathrm{PN}_{2}$. It follows that, late in the washout: $\dot{\mathrm{V}} \mathrm{AT}_{\mathrm{T}} \cdot \Delta \mathrm{P}_{\mathrm{A}_{2}}=\dot{\mathrm{V}}_{\mathrm{A}_{2}} \cdot \Delta \mathrm{P}_{\mathrm{A}_{2} \mathrm{~N}_{2}}$ and $\dot{\mathrm{Q}}_{\mathrm{T}} \cdot \Delta \mathrm{Pa}_{\mathrm{N}_{2}}=$ $\dot{Q}_{2} \cdot \Delta \mathrm{P}_{2 \mathrm{~N}_{2}}$, where the subscript $\mathrm{T}$ refers to total alveolar ventilation or total cardiac output. Since $\Delta \mathrm{PA}_{\mathbf{A N}_{2}}=$ $\Delta \mathrm{P}_{2 \mathrm{~N}_{2}}$, these two equations yield the ratio between those fractions of total alveolar ventilation and total perfusion, respectively, which are distributed to the poorly ventilated region:

$$
\left(\dot{\mathrm{V}}_{\mathrm{A}_{2}} / \dot{\mathrm{V}}_{\mathrm{AT}}\right) /\left(\dot{\mathrm{Q}}_{2} / \dot{\mathrm{Q}}_{\mathrm{T}}\right)=\Delta \mathrm{P}_{\mathrm{A}_{2}} / \Delta \mathrm{P}_{\mathrm{C}_{2}}
$$

At the end of the $\mathrm{N}_{2}$ washout this ratio is constant, since semilogarithmically plotted values of $\Delta \mathrm{P} \overline{\mathrm{A}}_{\mathrm{N}_{2}}$ and $\Delta \mathrm{P} \overline{\mathrm{c}}_{\mathrm{N}_{2}}$ are found to lie on parallel lines. When $\left(\dot{\mathrm{V}}_{\mathrm{A}_{2}} / \dot{\mathrm{V}}_{\mathrm{AT}}\right), \Delta \mathrm{P}_{\mathrm{A}_{2}}$ and $\Delta \mathrm{P}_{\mathrm{N}_{2}}$ are experimentally determined, $\dot{\mathrm{Q}}_{2} / \dot{\mathrm{Q}}_{\mathrm{T}}$ can be calculated. No attempt has been made to estimate the distribution of perfusion to compartments in the well venti-

${ }^{1}$ For present purposes we consider $\mathrm{N}_{2}$ washout complete when the forced end-expired $\mathrm{PN}_{2}$ is less than $4 \mathrm{~mm} \mathrm{Hg}$. lated region, because the assumptions that allow the calculation of $\mathrm{PC}_{\mathrm{N}_{2}}$ are not valid in the early portion of the $\mathrm{N}_{2}$ washout. The distribution of pulmonary blood flow is matched with the distribution of alveolar ventilation when the fractional perfusion equals the fractional ventilation of the poorly ventilated region.

The dilution index. A template was made in which $\log \{1 /[1+(1 / n)]\}^{n}$ is plotted against $n$. This was laid over the semilogarithmically plotted data and analyzed into linear components $(16,17)$ (Figure 1). The intersection of the curved template with each straight line gives a value of $n$ (on the baseline) which is the dilution index. This index, which is related to the turnover rate $(k)$ of Robertson, Siri and Jones (16) is the ratio FRC/VT - VD for each region.

The use of the dilution index and its determination by a template has proved to be a useful shortcut in the calculation of the functional residual capacity (FRC) and alveolar tidal volumes of the well and poorly ventilated regions. It also provides a simple characterization of the alveolar ventilation of any region.

Mixed expired alveolar versus end-tidal nitrogen concentrations. In our study we measured end-tidal $\mathrm{N}_{2}$ concen-

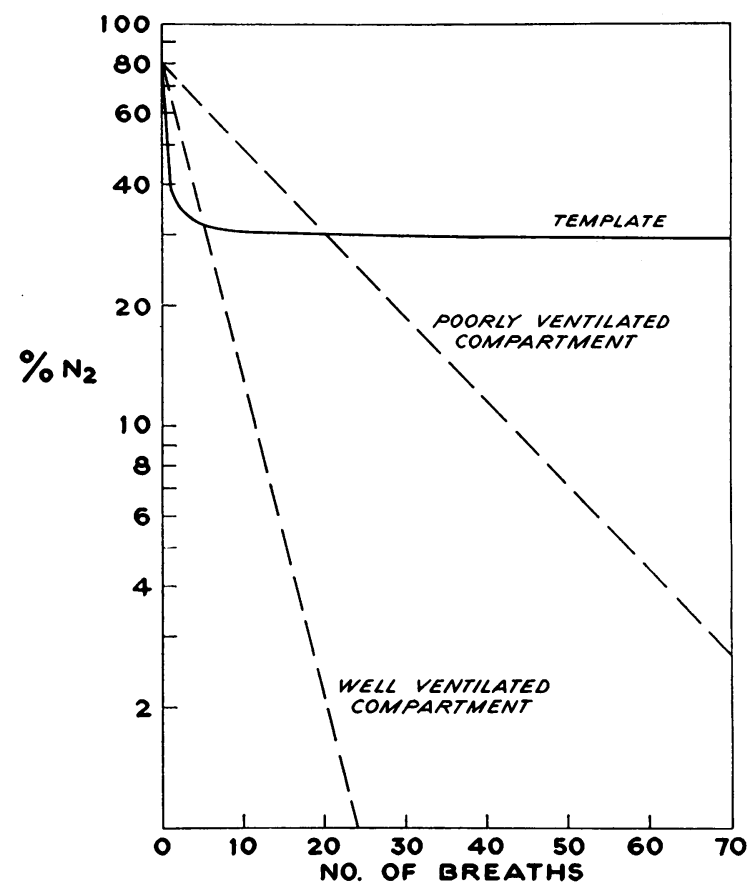

Fig. 1. Percentage of $\mathrm{N}_{2}$ concentration in endEXPIRED GAS ON LOGARITHMIC SCALE PLOTTED AGAINST NUMBER OF BREATHS FOR THE WELL AND POORLY VENTILATED REGIONS OF THE LUNG. The dotted lines represent the $\mathrm{N}_{2}$ washouts of the well and poorly ventilated compartments obtained from the $\mathrm{N}_{2}$ end-tidal washout. The dilution index template is superimposed on these graphs, giving an intercept value with the well ventilated region at breath 5 and with the poorly ventilated region at breath 20 . 


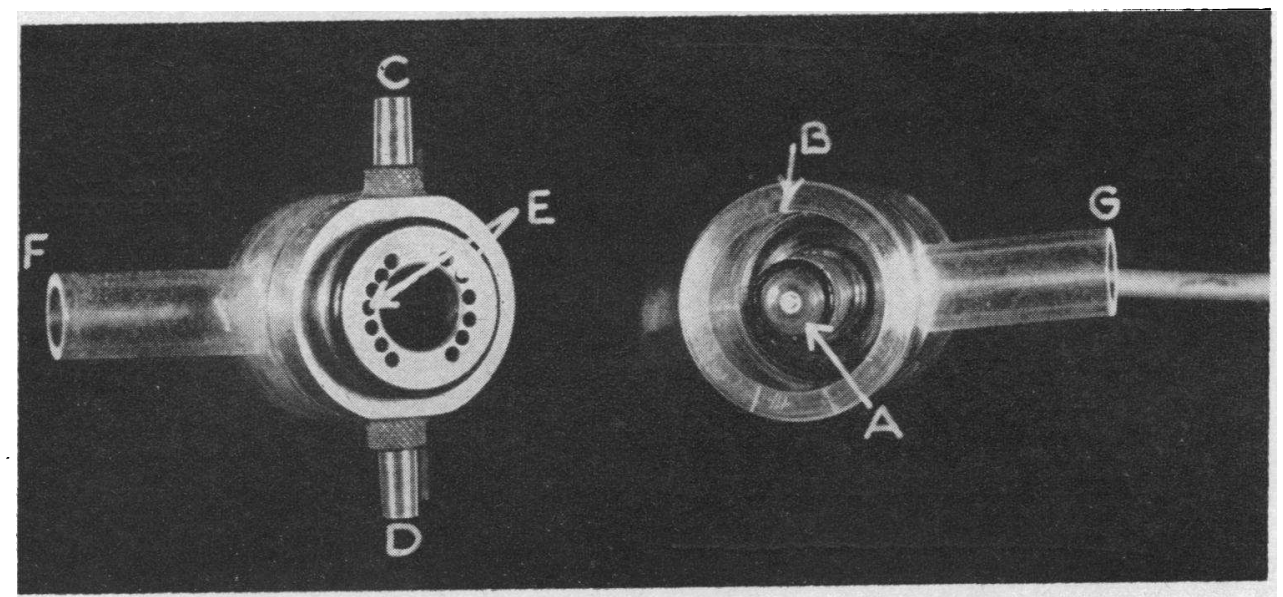

Fig. 2. Right, Clark $\mathrm{O}_{2}$ ELECTrode (A) in LUCITE JACKet (B) AND LEFT, THE FLOW-THROUGH CUVET (C-D) FOR THE ELECTRODE SHOWING THE HOLES (E) THAT ALLOW CIRCULATION THROUGH TUBES (F AND G) FROM THE WATERBATh AROUND CUVET AND ElECTRODE. The left-hand part fits snugly beneath the right-hand part and the membrane of the Clark electrode is in the flowing blood stream.

tration. The fact that these concentrations exceed mixed alveolar and mixed expired concentrations does not affect our determination of the dilution indices $n_{1}$ and $n_{2}$ (18). But this fact does necessitate the use of an additional piece of information in determining the absolute volumes and ventilations of the various regions. We have used the following relationship to determine alveolar ventilation for the less ventilated alveoli $(V T-V D)_{2}$ :

$$
(\mathrm{VT}-\mathrm{VD})_{2}=\frac{\mathrm{FRCT}-n_{1}(\mathrm{VT}-\mathrm{VD})}{n_{1}-n_{2}}
$$

Where FRCT, VT, and VD are, respectively, the total FRC, tidal volume, and dead space.

\section{METHODS AND MATERIAL}

The seated subject breathed from a system which delivered air or oxygen on demand. Inspired and expired gas were sampled continuously in the mouthpiece, and passed through an infrared $\mathrm{CO}_{2}$ meter and a $\mathrm{N}_{2}$ meter, both calibrated before and after each study with gases analyzed with the Scholander gas analyzer. While the subject breathed air, expired gas was collected for $3 \mathrm{~min}$ utes in a Neoprene metereological balloon. A sample was taken for $\mathrm{O}_{2}$ and $\mathrm{CO}_{2}$ analysis and the volume measured with a Tissot spirometer. Brachial arterial blood was sampled through an indwelling polyethylene catheter. Its $\mathrm{PCO}_{2}$ was measured with the Severinghaus $\mathrm{CO}_{2}$ electrode (19). During $\mathrm{N}_{2}$ washout studies arterial $\mathrm{O}_{2}$ tension was measured continuously with a Clark electrode placed in a temperature-controlled cuvet (Figure 2), through which blood flowed at a constant rate in a range of 5 to $10 \mathrm{ml}$ per minute. The data were recorded on a Grass polygraph (see Figures 3, 5 and 7). Barometric pressure was measured at each study and was used to calculate all tensions.

This flow-through $\mathrm{O}_{2}$ electrode was calibrated by analyzing samples of arterial blood at the beginning and the end of the $\mathrm{N}_{2}$ washout on a Severinghaus modification of the Clark $\mathrm{O}_{2}$ electrode (19). The Clark electrodes used in this study were slightly alinear over the 0 to 95 per cent $\mathrm{O}_{2}$ range. This alinearity occurred below 21 per cent $\mathrm{O}_{2}$, which affected the accuracy of the $\mathrm{Po}_{2}$ record in the earlier part of each study but not in the later part used in determining the distribution of perfusion. The final $\mathrm{Pa}_{2}$ used in each case was the constant highest value, regardless of the time required to attain it.

The reproducibility of the method was checked in dogs in which the arterial blood from the femoral artery that passed through the cuvet was returned continuously by vein. In 3 dogs studied this way repeated $\mathrm{N}_{2}$ washouts on a constant volume ventilator, and continuous recordings of $\mathrm{PaO}_{2}$ were identical for the individual dogs.

The arterial $\mathrm{Po}_{2}$ tracing lagged behind the tracings recorded at the mouth for two reasons. The first was the circulation time from the alveolar capillaries to the cuvet, which averaged about 12 seconds; this was measured as the time between the rise in alveolar $\mathrm{O}_{2}$ tension occurring during the first inhalation of $\mathrm{O}_{2}$ and the onset of the rise in arterial $\mathrm{PO}_{2}$. The second was the slow response time of the electrode; the mean time for 90 per cent response after a square wave rise in $\mathrm{Po}_{2}$ in either blood or gas was 9 seconds. Because the rate of rise of the arterial $\mathrm{O}_{2}$ tension was not constant during the $\mathrm{N}_{2}$ washout, it was necessary to correct the rate of rise in $\mathrm{O}_{2}$ tension for the electrode lag. The over-all lag was checked by having the patient perform a Valsalva maneuver for several seconds at the completion of the $\mathrm{N}_{2}$ washout. This maneuver causes a square-wave rise in $\mathrm{O}_{2}$ tension in the alveolar gas almost equal to the total rise in alveolar pressure. The time for a new plateau of arterial $\mathrm{O}_{2}$ tension to occur was approximately the same as the sum of the circulation time and time for 90 per cent electrode response, determined separately.

In addition to these studies, the following pulmonary function tests were performed: 7-minute $\mathrm{N}_{2}$ washout (20); 


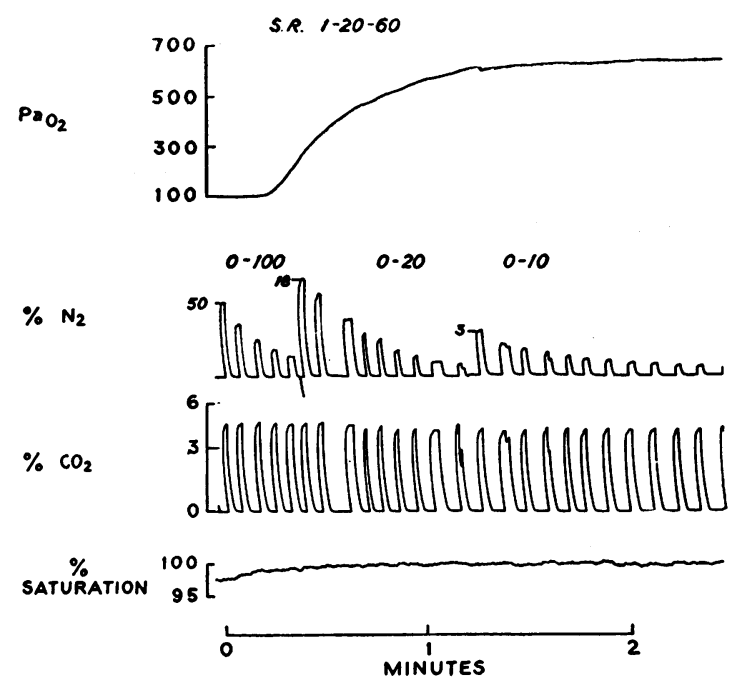

Fig. 3. Continuous Recording OF arterial $\mathrm{O}_{2}$ TENSION, END-TIDAL $\mathrm{N}_{2}$ AND $\mathrm{CO}_{2}$ CONCENTRATIONS AND EAR OXIMETER. Normal subject; inhalation of $\mathrm{O}_{2}$ beginning at 0 minutes.

FRC at the end of 7 minutes (20); single breath $\mathrm{O}_{2}$ test of distribution of inspired air (21); calculation of physiological dead space (22); maximal inspiratory and expiratory flow rates; and, on patients with interstitial fibrosis, pulmonary diffusing capacity (23). Anatomic dead space was estimated to be 30 per cent of the tidal volume. This value was chosen, since it represented the average PDS/ VT $\times 100$ in the normal subjects whose VT ranged from 420 to $970 \mathrm{ml}$.

\section{RESULTS}

Normal subjects. Figure 3 shows a typical recording. Both the $\mathrm{N}_{2}$ washout and the rise of arterial $\mathrm{O}_{2}$ tension are fast and "complete" in 20 breaths. Figure 4 shows the semilogarithmic plot of per cent $\mathrm{N}_{2}$ in end-tidal gas and capillary

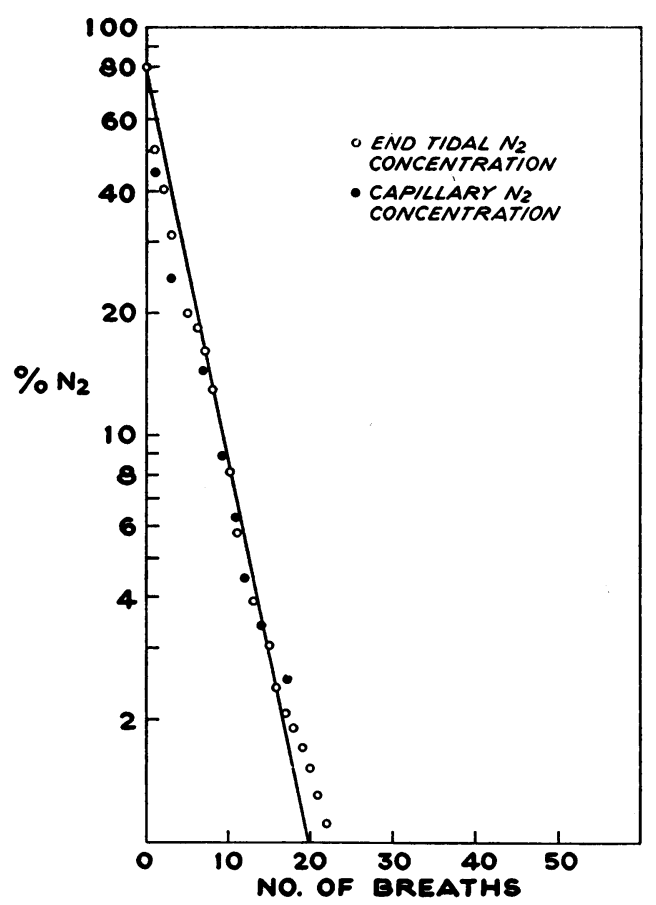

Fig. 4. PER CENT CONCENTRATION OF END-TIDAL AND CAPILLARY $\mathrm{N}_{2}$ PLOTTED ON LOGARITHMIC SCALE AGAINST NUMBER OF BREATHS FOR THE SAME SUBJECT OF FIGURE 3.

blood. The data in Table II show that the VA/ $\dot{Q}_{0}$ ratios are approximately the same in both the well and poorly ventilated regions despite the fact that the well ventilated region has considerably more ventilation per unit alveolar volume than has the poorly ventilated compartment. The two plots are superimposable.

Patients with pulmonary emphysema. Figure 5 shows that both the rise in arterial $\mathrm{O}_{2}$ tension

TABLE I

Results of pulmonary function tests (mean and range)

\begin{tabular}{|c|c|c|c|c|c|c|c|c|c|c|}
\hline Groups & Subjects & Age & FRC & S. B. $\mathrm{O}_{2} *$ & $\begin{array}{l}7 \text {-min } \mathrm{N}_{2} \\
\text { washout }\end{array}$ & $\mathrm{PDS} / \mathrm{VT}$ & $\begin{array}{l}\mathrm{PcO}_{2} \\
(\mathrm{a}-\mathrm{A})\end{array}$ & $\begin{array}{l}\mathrm{PaO}_{2} \\
\text { (air) }\end{array}$ & $\begin{array}{l}\mathrm{PaO}_{2} \\
\left(\mathrm{O}_{2}\right)^{2}\end{array}$ & Dco \\
\hline Normal & $\begin{array}{r}\text { no. } \\
9\end{array}$ & $\begin{array}{c}y r s \\
31 \\
21-38\end{array}$ & $\begin{array}{c}L \\
3.1 \\
2.2-3.9\end{array}$ & $\begin{array}{c}\% \mathrm{~N}_{2} \\
0.7 \\
0.0-2.4\end{array}$ & $\begin{array}{c}\% N_{2} \\
0.5 \\
0.5-0.7\end{array}$ & $\begin{array}{c}m l / m l \\
0.30 \\
0.27-0.35\end{array}$ & $\begin{array}{c}m m \mathrm{Hg} \\
1.5 \\
1.0-4.0\end{array}$ & $\begin{array}{c}m m H g \\
95 \\
85-105\end{array}$ & $\begin{array}{c}m m \mathrm{Hg} \\
645 \\
610-660\end{array}$ & $\begin{array}{c}\% \text { pred. } \\
115 \\
102-125\end{array}$ \\
\hline Emphysema & 15 & $\begin{array}{c}59 \\
44-76\end{array}$ & $\begin{array}{c}4.4 \\
3.1-6.2\end{array}$ & $\begin{array}{c}7.2 \\
2.1-13.0\end{array}$ & $\begin{array}{c}6.9 \\
2.3-17.2\end{array}$ & $\begin{array}{c}0.51 \\
0.33-0.67\end{array}$ & $\begin{array}{c}7.0 \\
2.0-13.0\end{array}$ & $\begin{array}{c}70 \\
60-90\end{array}$ & $\begin{array}{c}585 \\
460-640\end{array}$ & \\
\hline Interstitial fibrosis & 7 & $\begin{array}{c}45 \\
23-53\end{array}$ & $\stackrel{2.1}{1.3-3.2}$ & $\begin{array}{l}4.7 \\
1.0-11.0\end{array}$ & $\begin{array}{c}1.4 \\
1.0-2.2\end{array}$ & $\begin{array}{c}0.43 \\
0.33-0.59\end{array}$ & $\begin{array}{c}3.5 \\
0.0-8.0\end{array}$ & $\begin{array}{c}80 \\
65-90\end{array}$ & $\begin{array}{c}615 \\
565-660\end{array}$ & $\begin{array}{c}49 \\
23-67\end{array}$ \\
\hline $\begin{array}{l}\text { Mitral valv. dis. } \\
\quad+\text { pulm. hypertens. }\end{array}$ & 4 & $\begin{array}{c}43 \\
29-49\end{array}$ & $\stackrel{2.2}{1.0-3.0}$ & $\begin{array}{c}5.0 \\
4.0-6.0\end{array}$ & $\begin{array}{c}2.3 \\
0.6-3.4\end{array}$ & $\begin{array}{c}0.44 \\
0.37-0.55\end{array}$ & $\begin{array}{c}6.0 \\
4.0-9.0\end{array}$ & $\begin{array}{c}75 \\
55-80\end{array}$ & $\begin{array}{c}600 \\
580-615\end{array}$ & \\
\hline
\end{tabular}

* Single-breath oxygen test. 


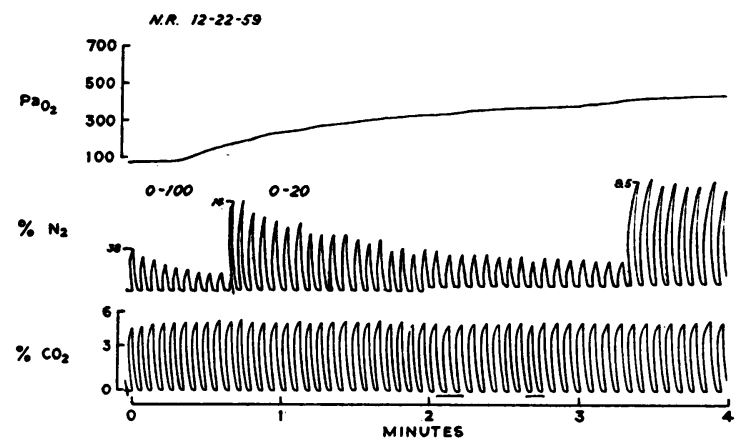

Fig. 5. Patient with emphysema; continuous ReCORDING OF ARTERIAL BLOOD $\mathrm{O}_{2}$ TENSION, END-EXPIRED $\mathrm{N}_{2}$ AND $\mathrm{CO}_{2}$ CONCENTRATIONS DURING INHALATION OF $\mathrm{O}_{2}$.

and the fall in alveolar $\mathrm{N}_{2}$ concentration are delayed. Although the delay is greater for the blood curve, this can best be determined by plotting semilogarithmically per cent $\mathrm{N}_{2}$ in end-tidal gas and capillary blood (Figure 6). There is a marked difference between the two, owing to overperfusion or underventilation of the poorly ventilated space. The shaded area represents the region selected for the calculation of ventilation and perfusion distribution to the poorly ventilated region. Table II shows that there is a marked difference in ventilation-perfusion ratios of the two regions in patients with emphysema. The percentage of the total ventilation distributed to the two regions is similar to that found in the normal subjects, but there is a marked increase in the volume of the poorly ventilated region so that the ventilation of this space is markedly reduced in relation to volume. In addition, there is a marked increase in perfusion

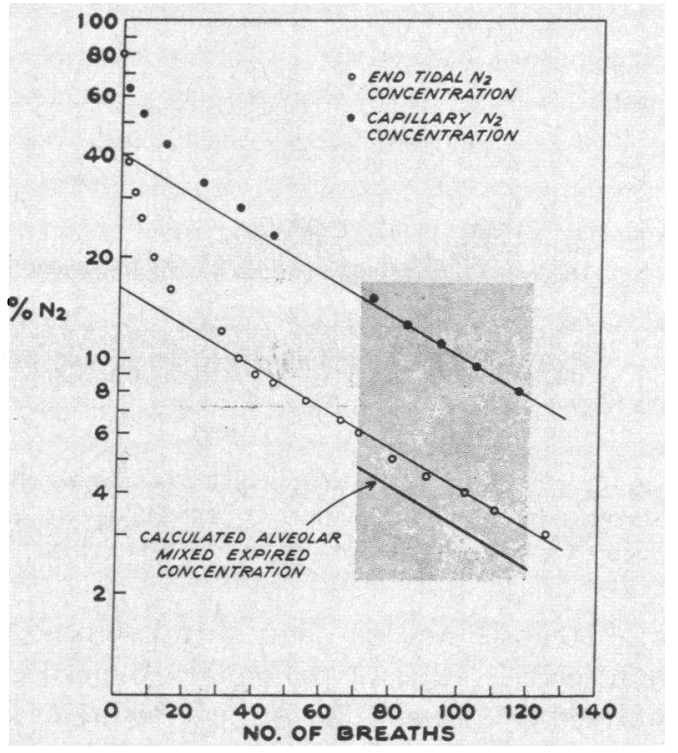

Fig. 6. Per Cent Concentration of END-tidal and CAPILlaRY $\mathrm{N}_{2}$ PLOTTED ON LOGARITHMIC SCALE AGAINST NUMBER OF BREATHS FOR THE PATIENT SHOWN IN FIGURE 5. The shaded area represents the portion of washout where calculation of distribution of ventilation, perfusion and mean expired alveolar $\mathrm{PN}_{2}$ was performed.

through the poorly ventilated region in terms of percentage of total pulmonary blood flow; in relation to volume, this perfusion is much the same as in the normal group. The reduced $\dot{V}_{A} / \dot{Q}_{c}$ ratio in the poorly ventilated space is reflected in the low arterial $\mathrm{O}_{2}$ tension when these patients breathe air and in the increase in PDS/ VT ratio and arterial end-tidal $\mathrm{Pco}_{2}$ differences.

Patients with mitral valvular disease and pul monary hypertension. Two subjects had pure

TABLE II

Distribution of functional residual capacity, ventilation, perfusion and the fractional ventilation to perfusion ratios of the well ventilated and poorly ventilated regions (mean and range) in normal subjects and patients with pulmonary and cardiac disease

\begin{tabular}{|c|c|c|c|c|c|c|c|c|}
\hline \multirow{2}{*}{$\begin{array}{l}\text { Groups, no. } \\
\text { Normal, } 9\end{array}$} & \multicolumn{4}{|c|}{ Well ventilated region } & \multicolumn{4}{|c|}{ Poorly ventilated region } \\
\hline & $\begin{array}{c}F R C \% \\
60 \\
14-100\end{array}$ & $\begin{array}{c}\dot{V} A \% \\
82 \\
58-100\end{array}$ & $\begin{array}{c}\dot{Q}_{c} \% \\
81 \\
50-100\end{array}$ & $\begin{array}{c}\dot{V} A \% / Q_{c} \% \\
1.03 \\
1.00-1.16\end{array}$ & $\begin{array}{l}F R C \% \\
40 \\
0-86\end{array}$ & $\begin{array}{l}\dot{V} A \% \\
18 \\
0-42\end{array}$ & $\begin{array}{l}\dot{Q}_{c} \% \\
19 \\
0-50\end{array}$ & $\begin{array}{c}\dot{V} A \% / \dot{Q}_{c} \% \\
0.92 \\
0.84-1.00\end{array}$ \\
\hline Emphysema, 15 & $\begin{array}{c}32 \\
8-69\end{array}$ & $\begin{array}{c}85 \\
74-95\end{array}$ & $\begin{array}{c}49 \\
34-63\end{array}$ & $\begin{array}{c}1.78 \\
1.35-2.42\end{array}$ & $\begin{array}{c}68 \\
31-92\end{array}$ & $\begin{array}{l}15 \\
5-26\end{array}$ & $\begin{array}{c}51 \\
37-66\end{array}$ & $\begin{array}{c}0.30 \\
0.11-0.56\end{array}$ \\
\hline $\begin{array}{l}\text { Interstitial } \\
\text { fibrosis, } 7\end{array}$ & $\begin{array}{c}39 \\
8-89\end{array}$ & $\begin{array}{c}81 \\
54-94\end{array}$ & $\begin{array}{c}59 \\
15-87\end{array}$ & $\begin{array}{c}1.65 \\
1.05-3.60\end{array}$ & $\begin{array}{c}61 \\
11-92\end{array}$ & $\begin{array}{l}19 \\
6-46\end{array}$ & $\begin{array}{c}41 \\
13-85\end{array}$ & $\begin{array}{c}0.51 \\
0.14-0.91\end{array}$ \\
\hline $\begin{array}{l}\text { Mitral valv. } \\
\text { dis. + pulm. } \\
\text { hypertens., } 4\end{array}$ & $\begin{array}{c}41 \\
39-45\end{array}$ & $\begin{array}{c}83 \\
75-90\end{array}$ & $\begin{array}{c}44 \\
22-67\end{array}$ & $\begin{array}{c}2.36 \\
1.35-3.64\end{array}$ & $\begin{array}{c}59 \\
55-61\end{array}$ & $\begin{array}{c}17 \\
10-25\end{array}$ & $\begin{array}{c}56 \\
33-78\end{array}$ & $\begin{array}{c}0.31 \\
0.26-0.33\end{array}$ \\
\hline
\end{tabular}




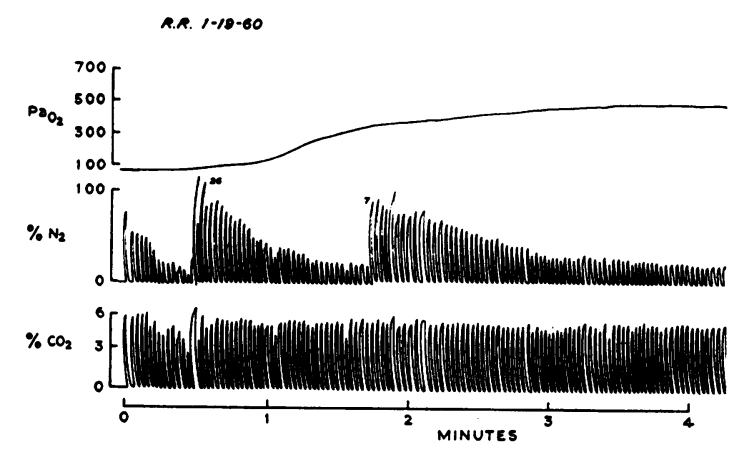

Fig. 7. Patient with mitral stenosis; continuous RECORDING OF ARTERIAL BLOOD $\mathrm{O}_{2}$ TENSION, END-TIDAL $\mathrm{N}_{2}$ AND $\mathrm{CO}_{2}$ CONCENTRATIONS DLRING INHALATION OF $\mathrm{O}_{2}$.

mitral stenosis, and two had mitral stenosis and insufficiency. All had pulmonary hypertension confirmed by pressure recordings during cardiac catheterization. A record from a patient with pure mitral stenosis and a mean pulmonary arterial pressure of $50 \mathrm{~mm} \mathrm{Hg}$ is shown in Figure 7. There is a very slow rise in arterial $\mathrm{O}_{2}$ tension. Tables I and II show unequal ventilationperfusion ratios similar to those found in the patients with emphysema. These findings were reflected in the increased PDS/VT ratios, the increased $\mathrm{PCO}_{2}$ differences between arterial blood and alveolar gas.

\section{DISCUSSION}

In developing the equations that allow calculation of end-capillary $\mathrm{N}_{2}$ tension, several assumptions were made. The first was that the pulmonary blood flow reached a fixed distribution pattern late in the $\mathrm{N}_{2}$ washout; i.e., the fractional blood flow through the well and poorly ventilated region became constant. This merely implies that any changes due to $\mathrm{O}_{2}$ were proceeding at a negligible rate near the end of the $\mathrm{O}_{2}$ breathing period when our determinations were made. The perfusion distribution calculated by this method is that which occurs during pure ogyxen breathing.

The second assumption is that the right-to-left anatomical shunt becomes a fixed fraction of the pulmonary blood flow during $\mathrm{N}_{2}$ washout. In normal subjects the anatomical shunt becomes constant when alveolar $\mathrm{Po}_{2}$ is raised stepwise (16).

The third assumption is that the arteriovenous $\mathrm{O}_{2}$ content difference $\left(\mathrm{C}_{\mathrm{a}}-\mathrm{C}_{\overline{\mathrm{v}}}\right)$ reaches a constant value over the latter part of the washout. There is no reason why this should change at a time when the subject is virtually in a steady state.

The fourth assumption, that diffusion barriers present no impediment when $\mathrm{PA}_{\mathrm{O}_{2}}$ is high, is valid and has already been discussed under Theory.

The fifth assumption, that the $\mathrm{PCO}_{2}$ is constant, though at various values in different regions, is valid in a steady state such as this.

The last assumption is that the lung can be divided into only a well and a poorly ventilated region. This assumption permits the calculation of mixed alveolar $\mathrm{PN}_{2}$ from the end-tidal $\mathrm{PN}_{2}$ graph. In order to check the reasonableness of this assumption, a model lung with a distribution of ventilatory regions varying over a wide range was constructed mathematically. When this model was subjected to a $\mathrm{N}_{2}$ washout, and the alveolar $\mathrm{PN}_{2}$ was plotted on two-cycle semilogarithmic paper, only two regions could be found by the graphical technique (24). The two-ventilatory-region simplification is practical as well as convenient. The use of the 7-minute FRC to calculate the fractional ventilation to the poorly ventilated region is convenient but, in patients with chronic pulmonary emphysema, introduces a small inaccuracy. A recent study (25) has shown that the conventional 7-minute FRC measured by the $\mathrm{N}_{2}$ washout method underestimates the prolonged $\mathrm{N}_{2}$ washout FRC by 19 to 48 per cent in patients with chronic pulmonary emphysema. In this laboratory the 7-minute FRC measured by the $\mathrm{N}_{2}$ open-circuit and the closed-circuit methods underestimated the 18minute FRC by an average of $980 \mathrm{ml}$ in $13 \mathrm{pa}-$ tients with chronic pulmonary emphysema (26). Using the 18 -minute rather than the 7 -minute FRC value increases the ventilation to the poorly ventilated region approximately 20 per cent, or an increase from 15 to 18 per cent in the value $V_{A}$ per cent to the poorly ventilated region in Table II.

The contributions of $\mathrm{N}_{2}$ from the inspired $\mathrm{O}_{2}$ tank and from the tissues have a virtually constant effect and so do not influence the various values of $\Delta \mathrm{PN}_{2}$ used here, which are differences from the final state. Hence the ratio $\Delta \mathrm{P}_{\mathrm{A}_{2}} /$ $\Delta \mathrm{P} \overline{\mathrm{c}}_{\mathrm{N}_{2}}$ is not affected.

Measurement of arterial $\mathrm{PO}_{2}$ during the $\mathrm{N}_{2}$ 
washout can be made continuously, as here, or by drawing individual samples at different times during the washout. The accuracy of $\mathrm{Pa}_{2}$ measurements in the high $\mathrm{Po}_{2}$ range is $\pm 5 \mathrm{~mm}$ $\mathrm{Hg}$. The advantage of the directly recorded $\mathrm{PaO}_{2}$ is that $\mathrm{Pa}_{2 f}-\mathrm{PaO}_{2 t}$ can be graphed over the entire $\mathrm{N}_{2}$ washout and the proper range can be selected late in the washout when the slopes of $P \overline{\mathrm{A}}_{\mathrm{N}_{2}}$ and $\mathrm{P} \overline{\mathrm{C}}_{\mathrm{N}_{2}}$ are parallel.

The results show that in normal subjects the ratio of ventilation to perfusion is approximately the same for both the well and the poorly ventilated regions. This finding is in agreement with the results obtained by other methods (3) and is to be expected from the normal values for pulmonary function obtained in these subjects.

In the patients with emphysema, there was a consistently lower ventilation-perfusion ratio in the poorly ventilated region. The perfusion of the two regions in the patients with emphysema was more closely related to the volume of the region than to its ventilation. This confirms work recently published by Briscoe and associates (11). This can be interpreted in two ways. One is that the poorly ventilated region represents the more normal lung tissue which is still normally perfused, while the well ventilated area represents tissue with increased compliance and ventilation in which there has been loss of capillary bed. Another is that the reverse situation exists and the poorly ventilated region represents the more diseased areas in which ventilation is markedly inadequate and perfusion is still relatively in excess of the inadequate ventilation. Further studies are needed to establish correlations between the physiological findings such as ours and the anatomical distribution of the alveolar and capillary lesions in patients with emphysema.

The results in patients with fibrosis showed great variation and are difficult to interpret. In some patients the ventilation-perfusion relationships appeared relatively normal, while in others the findings were similar to those in patients with emphysema. These findings are consistent with those of others $(27,28)$.

In the patients with mitral disease and pulmonary hypertension, there were abnormalities of ventilation-perfusion relationships similar to those seen in patients with emphysema. It has been shown (29) that the distribution of the pulmonary vascular lesions in such patients is not uniform. The greatest medial hypertrophy and intimal thickening is found in the bases, while the apical regions of the lungs are relatively normal. It is possible that the abnormalities in $\dot{\mathrm{V}}_{\mathrm{A}} / \dot{\mathrm{Q}}_{\mathrm{c}}$ in our patients with mitral stenosis and pulmonary hypertension are due to these differences in the pulmonary vasculature.

\section{SUMMARY}

1. A new method is described for obtaining quantitative data on distribution of pulmonary capillary blood flow through well and poorly ventilated regions of the lungs. It requires continuous or repeated analyses of alveolar $\mathrm{PN}_{2}$ and arterial $\mathrm{Po}_{2}$ during inhalation of $\mathrm{O}_{2}$.

2. End-capillary $\mathrm{PN}_{2}$ is calculated from the arterial $\mathrm{O}_{2}$ tension during the $\mathrm{N}_{2}$ washout.

3. The ratio of $P \bar{A}_{N_{2}}$ to $P \bar{C}_{N_{2}}$ late in the washout gives the ratio of fractional ventilation to fractional perfusion through the poorly ventilated space.

4. Unevenness of perfusion exists when the fractional perfusion is in excess of fractional ventilation to the poorly ventilated space.

5 . Normal subjects have no unevenness of perfusion in relation to ventilation.

6. Patients with emphysema have marked unevenness of perfusion in relation to ventilation but not in relation to lung volume.

7. Patients with interstitial fibrosis may have unevenness of perfusion in relation to ventilation.

8. Patients with mitral valvular disease and pulmonary hypertension have unevenness of perfusion in relation to ventilation.

\section{REFERENCES}

1. Gurtner, H. P., Briscoe, W. A., and Cournand, A. Studies of the ventilation-perfusion relationships in the lungs of subjects with chronic pulmonary emphysema, following a single intravenous injection of radioactive krypton $\left(\mathrm{Kr}^{85}\right)$. I. Presentation and validation of a theoretical model. J. clin. Invest. 1960, 39, 1080.

2. Dollery, C. T., and West, J.'B. Regional uptake of radioactive oxygen, carbon monoxide and carbon dioxide in the lungs of patients with mitral stenosis. Circulat. Res. 1960, 8, 765.

3. West, J. B., and Dollery, C. T. Distribution of blood flow and ventilation-perfusion ratio in the lung, measured with radioactive carbon dioxide. J. appl. Physiol. 1960, 15, 405. 
4. Fowler, W. S., and Comroe, J. H., Jr. Lung function studies. I. The rate of increase of arterial oxygen saturation during the inhalation of 100 per cent $\mathrm{O}_{2}$. J. clin. Invest. 1948, 27, 327.

5. Perkins, J. F., Jr., Adams, W. E., and Flores, A. Arterial oxygen saturation vs. alveolar oxygen tension as a measure of venous admixture and diffusion difficulty in the lung. J. appl. Physiol. 1956, 8, 455.

6. Scherrer, M. Das Studium der intrapulmonalen Gasmischung zur Beurteilung der in gleichmässingen Ventilation und Perfusion der Lungen. Proc. kon. ned. Akad. Wet., ser. C. 1955, 58, 84.

7. Martin, C. J., and Young, A. C. Ventilation-perfusion variations within the lung. J. appl. Physiol. 1957, 11, 371.

8. West, J. B., Fowler, K. T., Hugh-Jones, P., and O'Donnell, T. V. Measurement of the ventilationperfusion ratio inequality of the lung by analysis of a single expirate. Clin. Sci. 1957, 16, 529.

9. Klocke, F. J., and Rahn, H. The arterial-alveolar inert gas (" $\mathrm{N}_{2}$ ") difference in normal and emphysematous subjects, as indicated by the analysis of urine. J. clin. Invest. 1961, 40, 286.

10. Briscoe, W. A., and Gurtner, H. P. The alveolo urinary $\mathrm{N}_{2}$ partial pressure difference compared to other measures of the distribution of ventilation and perfusion within the lung. Fed. Proc. 1960, $19,381$.

11. Briscoe, W. A., Cree, E. M., Filler, J., Houssay, H. E. J., and Cournand, A. Lung volume, alveolar ventilation and perfusion interrelationships in chronic pulmonary emphysema. J. appl. Physiol. 1960, 15, 785.

12. Pappenheimer, J. R., and others. Standardization of definitions and symbols in respiratory physiology. Fed. Proc. 1950, 9, 602.

13. Berggren, S. The oxygen deficit of arteria blood caused by non-ventilating parts of the lung. Acta physiol. scand. 1942, 4, suppl. 11.

14. Bartels, H., and Rodewald, G. Die alveolär-arterielle Sauerstoffdruckdifferenz und das Problem des Gasaustausches in der menchlichen Lunge. Pflüg. Arch. ges. Physiol. 1953, 258, 163.

15. Finley, T. N., Swenson, E. W., and Comroe, J. H., Jr. The cause of arterial hypoxemia at rest in patients with "alveolo-capillary block." Submitted for publication.

16. Robertson, J. S., Siri, W. E., and Jones, H. B. Lung ventilation patterns determined by analysis of nitrogen elimination rates; use of the mass spectrom- eter as a continuous gas analyzer. J. clin. Invest. 1950, 29, 577.

17. Fowler, W. S., Cornish, E. R., Jr., and Kety, S. S. Lung function studies. VIII. Analysis of alveolar ventilation by pulmonary $\mathrm{N}_{2}$ clearance curves. J. clin. Invest. 1952, 31, 40.

18. Briscoe, W. A., and Cournand, A. C. Uneven ventilation of normal and diseased lungs studied by an open circuit method. J. appl. Physiol. 1959, 14, 284.

19. Severinghaus, J. W., and Bradley, A. F. Electrodes for blood $\mathrm{Po}_{2}$ and $\mathrm{PCO}_{2}$ determination. J. appl. Physiol. 1958, 13, 515.

20. Cournand, A., Baldwin, E. DeF., Darling, R. C., and Richards, D. W., Jr. Studies on intrapulmonary mixture of gases. IV. The significance of the pulmonary emptying rate and a simplified open circuit measurement of residual air. J. clin. Invest. 1941, 20, 681.

21. Comroe, J. H., Jr., and Fowler, W. S. Lung function studies. VI. Detection of uneven alveolar ventilation during a single breath of oxygen. Amer. J. Med. 1951, 10, 408.

22. Riley, R. L., Cournand, A., and Donald, K. W. Analysis of factors affecting partial pressures of oxygen and carbon dioxide in gas and blood of lungs: Methods. J. appl. Physiol. 1951, 4, 102.

23. Ogilvie, C. M., Forster, R. E., Blackmore, W. S., and Morton, J. W. A standardized breath holding technique for the clinical measurement of the diffusing capacity of the lung for carbon monoxide. J. clin. Invest. 1957, 36, 1.

24. Finley, T. N. Unpublished data.

25. Emmanuel, G., Briscoe, W. A., and Cournand, A. A method for the determination of the volume of air in the lungs: Measurements in chronic pulmonary emphysema. J. clin. Invest. 1961, 40, 329.

26. Tierney, D. F., Nadel, J. A., and Comroe, J. H., Jr. Total ("plethysmographic") and communicating ("washout") lung volumes in patients with emphysema. Clin. Res. 1961, 9, 76.

27. Read, J., and Williams, R. S. Pulmonary ventilation. Blood flow relationships in interstitial disease of the lungs. Amer. J. Med. 1959, 27, 545.

28. Holland, R. A. B. Physiologic dead space in the Hamman-Rich syndrome. Physiologic and clinical applications. Amer. J. Med. 1960, 28, 61.

29. Doyle, A. E., Goodwin, J. F., Harrison, C. V., and Steiner, R. E. Pulmonary vascular patterns in pulmonary hypertension. Brit. Heart J. 1957, 19, 353. 